\title{
Master of Science in Law
}

National Cancer Institute

\section{Source}

National Cancer Institute. Master of Science in Law. NCI Thesaurus. Code C71381.

A postgraduate academic degree awarded after the completion of a program of one to three years in duration. This acknowledgment comprises about 4-6 years of university study in total with a focus on law. 